\title{
Grazing and plant growth interactions in a semiarid Fes- tuca pallescens grassland (Patagonia)
}

\author{
MÓNICA B. BERTILLER AND GUILLERMO E. DEFOSSÉ
}

\section{Abstract}

The effects of grazing on relative $\left(g \cdot g^{-1} \cdot d^{-1}\right)$ and absolute $\left(g \cdot m^{-2} \bullet d^{-1}\right)$ aboveground net primary productivity and senescence of coirón blanco (Festuca pallescens (St. Yves) Parodi) were investigated in northwestern Patagonia. Aboveground net primary productivity under ungrazed and grazed conditions was estimated by means of a simulation model fitted to biomass data. Relative and absolute aboveground net primary productivity was greater for grazed than ungrazed plants during the early growing season while the inverse occurred during the late growing season (reproductive period). Grazing reduced the relative and absolute aboveground senescence during the late growing season. Relative and absolute effective primary productivity, expressed as the difference between the corresponding primary productivity and senescence, were greater for grazed than ungrazed plants. This increase is in accordance with the grazing optimization hypothesis. However, the increase was not of sufficient magnitude to compensate for losses of green biomass caused by grazing. Results imply that current grazing intensities in this region reduce aboveground productivity of coirón blanco. It follows that a reduction in stocking rates would be necessary to increase aboveground primary productivity.

Key Words plant-herbivore interaction, primary productivity, senescence, simulation model

The negative impacts of defoliation by grazing may be partially or competely negated by other plant responses such as increased photosynthesis, decreased senescence, decreased self-shading of green tissues, etc. (McNaughton 1979, Hilbert et al. 1981, Wallace et al. 1984, Belsky 1986, Williamson et al. 1989). Some of these compensatory effects have been presented in the form of a grazing optimization hypothesis (McNaughton 1979, Hilbert et a. 1981) which predicts changes in the aboveground primary productivity caused by different grazing intensities. These effects are of interest for an adequate management of grazing areas.

The patterns of interaction between herbivores and grasses in Patagonia are practically unknown (Soriano 1983). In northwestern Patagonia, an area of about $5,200 \mathrm{~km}^{2}$ of semiarid grassland dominated by coirón blanco (Festuca pallescens (St. Yves) Parodi), has been extensively grazed by sheep since the beginning of this century. Grazing has modified the productive potential of coiron blanco in this region, reduced its cover, and in some extreme situations it has been replaced by other perennial shrubby species (Ares et al. in press).

The present study was designed to examine the functional aspects of grazing relative to its effects on coiron blanco and to compare the responses of changes in aboveground primary productivity of this species with those to be expected based on the grazing optimization hypothesis (McNaughton 1979, Hilbert et al. 1981).

Authors are associate researcher and research fellow, respectively, Centro Nacional Patagónico, CONICET, 28 de Julio 28, 9120 Puerto Madryn, Chubut, Argentina.

Manuscript accepted 13 November 1989.

\section{Methods and Materials}

\section{Study Site}

Study was conducted during 2 growing cycles (1981-1983) at Media Luna Ranch $\left(45^{\circ} 36^{\prime} \mathrm{S}, 71^{\circ} 25^{\prime} \mathrm{W}\right)$, located in the southwest of the Chubut Province (northwestern Patagonia, Argentina). Average annual precipitation (1974-1984) is $374 \mathrm{~mm}$. Average annual temperature is $4.6^{\circ} \mathrm{C}$. Soils are sandy to sandy-loam textured without a clear horizon differentiation (Beeskow et al. 1987).

Grazing treatment was a 700 ha allotment containing a representative stand of the coirón blanco grassland steppe (Ares et al. in press) characteristic of the Subandean Floristic district (Soriano 1956). Greater than $95 \%$ of the total biomass is coiron blanco, which is considered to be one of the best Patagonian forage species (Boelcke 1957). The allotment was located in the alluvial plains of the Mayo River (630 m.a.s.1.), which are used as winter ranges because of their favorable topographic and microclimatic characteristics. Each year, the allotment was grazed from May to December with 6-month old Corriedale lambs at a rate of about 2.1 lambs/ha.

\section{Field Sampling}

Plant biomass samples were collected from the grazed area from May 1981 to March 1983 at 3-month intervals. On each sample date, 10 circular ( $1 \mathrm{~m}$ diameter) plots were randomly located and the phenological growth stage (vegetative or reproductive growth) of coirón blanco recorded. Aerial biomass was then clipped at the soil surface and sorted into 4 categories: (1) green biomass; (2) dry biomass (no longer living but without signs of deterioration); (3) dead biomass (last year's dead with signs of deterioration); and (4) litter. The plant material was ovendried at $70^{\circ} \mathrm{C}$ and weighed.

Biomass samples were also collected at monthly to bimonthly intervals from a 2-ha exclosure constructed in April 1981 and located within the study allotment. Sample techniques and processing were similar to those in the grazed area.

\section{Model Development}

The interaction between forage removal and plant productivity was examined using compartmental analyses of plant growth procedures (Nemchenko 1987). Amount of green biomass removed was estimated, based on average metabolic data (Scott 1982), at 500 to $800 \mathrm{~g}$ of dry matter per day per animal. This values were used to represent a reasonable range of daily removal rates of coiron blanco, to be used in compartment simulation models. Based on Ares (1978) and Bertiller (1984) the following plant compartments (state variables) were defined to describe biomass dynamics within exclosure: green $\left(X_{1}\right)$, dry $\left(X_{2}\right)$, dead $\left(X_{3}\right)$ and litter $\left(X_{4}\right)$. A system of first order linear differential equations (Kowal 1971) was defined.

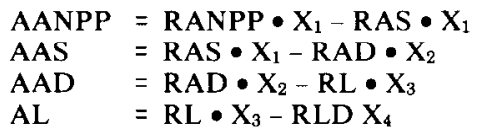

where RANPP, RAS, RAD, RL, and RLD (the model coefficients) represent the relative rates of ecosystem processes. Relative 
aboveground net primary productivity (RANPP) (analogous to relative growth rate (Milthorpe and Moorby 1979)), relative aboveground senescence (RAS), relative aboveground death (RAD), relative littering $(R L)$, and relative litter decomposition (RLD) are expressed in mass/unit mass/time $\left(g \bullet g^{-1} \bullet d^{-1}\right)$. The time derivatives of the state variables of the model (AANPP, AAS, AAD and $\mathrm{AL}$ ) represent the absolute rates of the ecosystem processes. Absolute aboveground net primary productivity (AANPP), absolute aboveground senescence (AAS), absolute aboveground death (AAD), and absolute littering (AL) are expressed in mass/ground area/time $\left(g \bullet \mathrm{m}^{-2} \bullet \mathrm{d}^{-1}\right)$. The model coefficients are time constant during the interval between 2 samplings, and were computed by convergent iteration, at daily intervals, until the calculated biomass values fit those measured in the field plots, within the confidence interval $(p=0.05)$ of the sampling estimates. The simulation procedure and the criteria to minimize the coefficient values have been explained in detail by Bertiller (1984).

The same procedure was used to generate the coefficients for the grazed area. In this case, equation 1.1 was replaced by:

$$
\text { AANPP }=\text { RANPP } \bullet \mathrm{X}_{1}-\mathrm{RAS} \cdot \mathrm{X}_{1}-\mathrm{G}
$$

where $G$ represents the amount of green biomass removed per unit of ground area per day $\left(\mathrm{g} \bullet \mathrm{g}^{-2} \bullet \mathrm{d}^{-1}\right)$. Two sets of model coefficients for $\mathrm{G}=0.16$ and $\mathrm{G}=0.10 \mathrm{~g} \bullet \mathrm{m}^{-1}$ were computed, corresponding to upper and lower possible grazing intensities of coirón blanco, uniformly distributed over the landscape. Both $G$ values were estimated from Scott's (1982) metabolic requirements and the actual stocking rates occurring in the paddock during the sampling period.

Other plant growth variables for both ungrazed and grazed treatments, were defined as follows:

-REAPP $\left(\mathrm{g} \cdot \mathrm{g}^{-1} \cdot \mathrm{d}^{-1}\right)=$ RANPP - RAS; (relative effective aboveground primary productivity)

$-\operatorname{AEAPP}\left(\mathrm{g} \bullet \mathrm{m}^{-2} \bullet \mathrm{d}^{-1}\right)=$ AANPP - AAS; (absolute effective aboveground primary productivity)

-EBI $\left(\mathrm{g} \cdot \mathrm{m}^{-2} \cdot \mathrm{d}^{-1}\right)=$ AEAPP $-\mathrm{G}$; (effective biomass increase per unit of ground area)

AEAPP and EBI are conceptually equivalent to herbage growth rate (HGR) and net herbage accumulation rate (NHAR), respectively, as defined by Scarnecchia and Kothmann (1986). The time series of relative and absolute primary productivity (RANPP, REAPP, AANPP, AEAPP, and EBI) and senescence (RAS and AAS) for grazed plots ( $y$ ') were compared with those computed for ungrazed plots $(y)$, using a linear regression model of the form: $\mathrm{y}^{\prime}=$ $a_{0}+a_{1} y$. The amount of the variance explained by this regression model was used as an indication of the linear correlation between the time series from grazed and ungrazed treatments. Other comparative characteristics of the time series were quantified through the regression parameters $a_{0}$ and $a_{1}$. Differences in the seasonality of the processes were indicated by negative slopes $\left(a_{1}<0\right)$ while differences in the intensity of the processes was inferred from inspection of slopes $\left(a_{1}\right)$ and intercepts $\left(a_{0}\right)$. A test of $\mathrm{H}_{0}: \mathrm{a}_{0}=0$ and $H_{0}: a_{1}=1$ was used to find significant differences between treatments in the magnitude of the plant processes. Unless otherwise noted, the level of significance throughout this study is $p<0.05$.

\section{Results}

\section{Biomass Dynamies and Underlying Model Assumptions}

Field data and the dynamics of the different biomass categories of coirón blanco in the grazed and ungrazed treatments calculated by fitting the equations 1.1 to 1.4 are shown in Figure 1. During the period from 1981 to 1983 , greater amounts of standing biomass
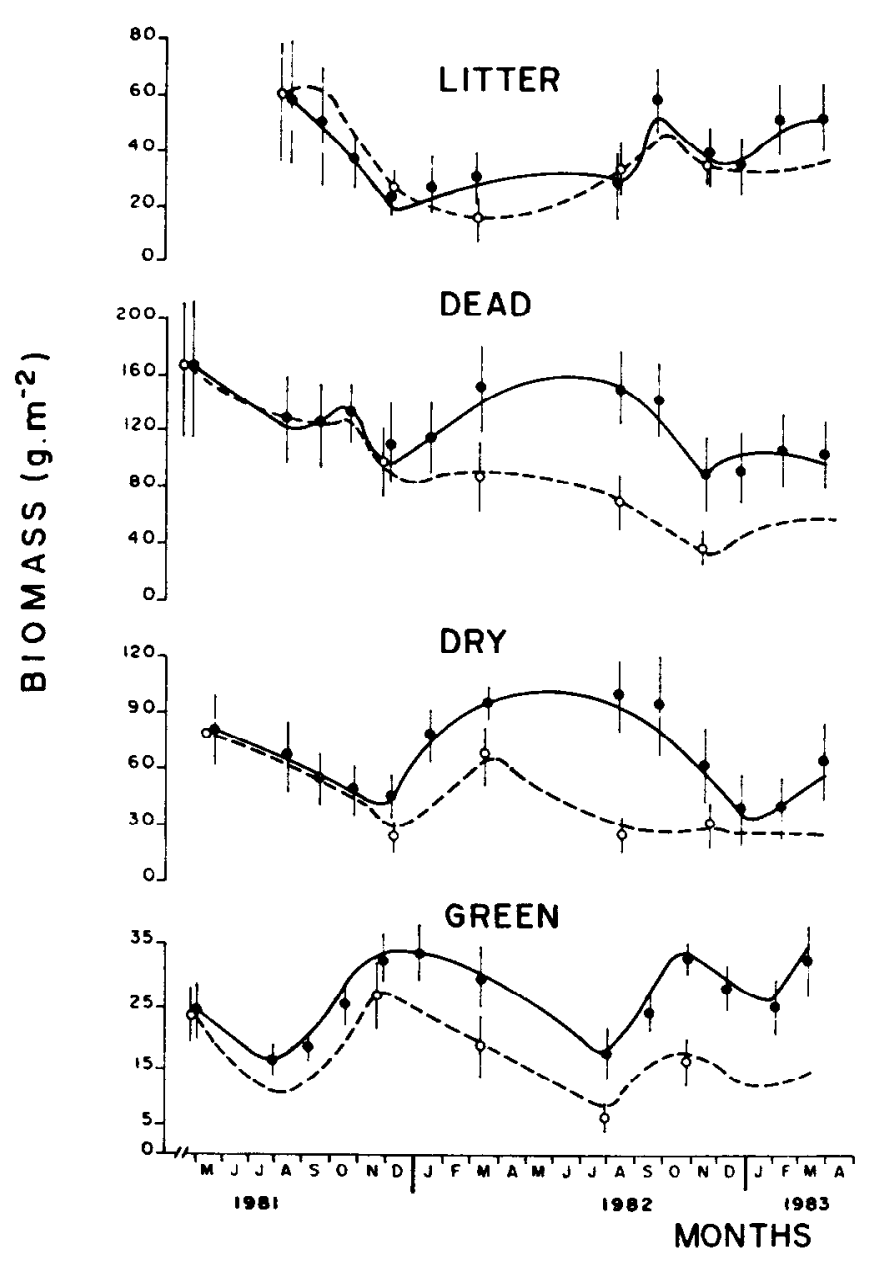

Fig. 1. Changes in green, dry, dead, and litter biomass in ungrazed (solid line) and grazed (dashed line) treatments. Lines indicate values obtained with model 1.1-1.4. Solid and open symbols correspond to measured biomass in ungrazed and grazed treatments respectively. Confidence interval is at $\mathbf{p}=0.05$.

(green, dry, and dead) were observed in the ungrazed than grazed area. No significant differences between grazed and ungrazed treatments were observed in the litter compartment. Pcak green biomass occurred in spring (October-December) in both grazed and ungrazed treatments and minimums occurred during winter. Dry biomass in both treatments peaked in fall. However rates of disappearance were greater during the winter months in the grazed than ungrazed treatment. Minimums were observed at the end of spring in both the grazed and ungrazed treatments. Amount of litter peaked in both treatments at the end of winter.

Possible shortcomings of the assumptions of the model used for ungrazed plants were detailed in Bertiller (1984) and would not affect these estimates. Inspections of the litter components to detect whether direct transfer through trampling occurred from green or dry tissues, indicated that this was not quantitatively important. The low impact of trampling in these grasslands is related to persistence of lamina, the erect growth form of coiron blanco bunches, and the low soil cover ( $55 \%$ or less), which provides sufficient space for sheep to step between rather than on individual plants. However underestimates of trampling waste, if 


\begin{tabular}{|c|c|c|c|}
\hline o. & do & O, & $F$ \\
\hline$G=0.10$ & $\begin{array}{c}0.007 \\
10.0051\end{array}$ & $\begin{array}{c}0.61 \\
|0.14| \\
\end{array}$ & $18.31^{++}$ \\
\hline$G=C$ & $\begin{array}{c}0.011 \\
(0.004)\end{array}$ & $\begin{array}{r}0.57 \\
10.211\end{array}$ & 7.48 \\
\hline
\end{tabular}

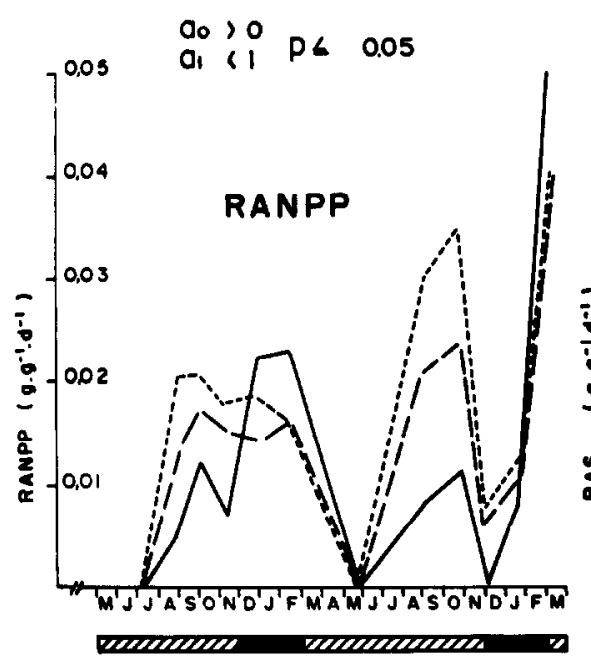

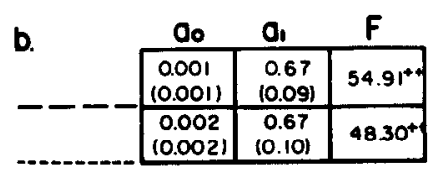

$a_{0}=0$

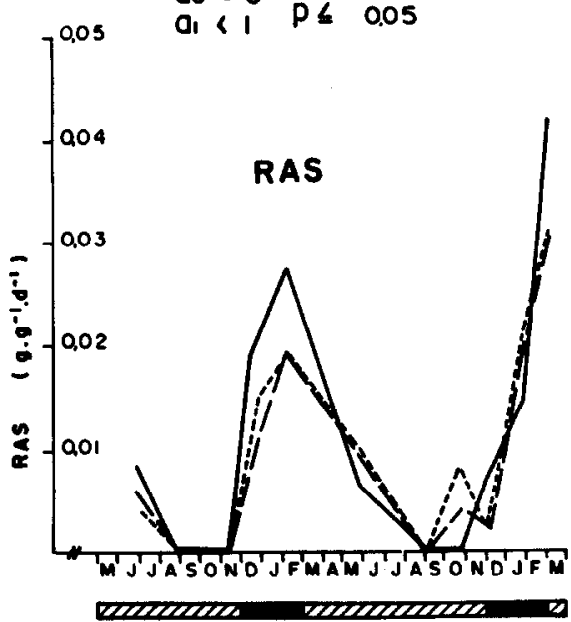

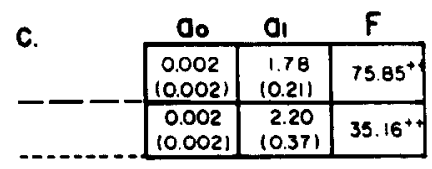

$a_{0}=0$

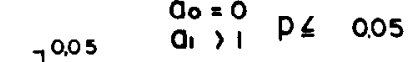

a, >

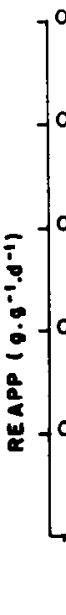

RE APP

000 vegetative period

REPRODUCTIVE PERIOD

Fig. 2. Seasonal trends for (a) RANPP, (b) RAS, and (c) REAPP in ungrazed (solid line) and grazed (long dashed line: $G=0.10$, short dashed line: G=0.16 $\left.\mathrm{g} \bullet \mathrm{m}^{-2} \bullet \mathrm{d}^{-1}\right)$ treatments. Model coefficients and significance levels $\left(p=0.05^{+}, p=0.01^{++}\right)$contrasting grazed and ungrazed treatments are presented at top of figure.

they would occur, could result in overestimation of RAS, RAD, RL, AAS, AAD, or AL rates in grazed treatments.

\section{Effects of Grazing}

Relative aboveground net primary productivity (RANPP, Fig.
$2 a)$ in the ungrazed treatment was greater from December to March (summer), coincidently with the reproductive period. On the contrary, maximum RANPP in the grazed area $(G=0.10$ and $G=0.16\left(g \bullet \mathrm{m}^{-2} \bullet \mathrm{d}^{-1}\right)$ was observed earlier in the growing season (August to November), during the vegetative period, and exceeded

\begin{tabular}{|c|c|c|c|}
\hline & Oo & $\mathbf{a}_{\mathbf{1}}$ & $F$ \\
\hline$G=0.10$ & $\begin{array}{c}0.107 \\
10.032\end{array}$ & $\begin{array}{c}0.25 \\
(0.06)\end{array}$ & \\
\hline & $\begin{array}{c}0.155 \\
(0048)\end{array}$ & $\begin{array}{c}0.24 \\
(0.03)\end{array}$ & 8.0 \\
\hline
\end{tabular}

$\begin{aligned} & 0 .>0 \\ & 0,<1\end{aligned} \quad p \leq 0.05$

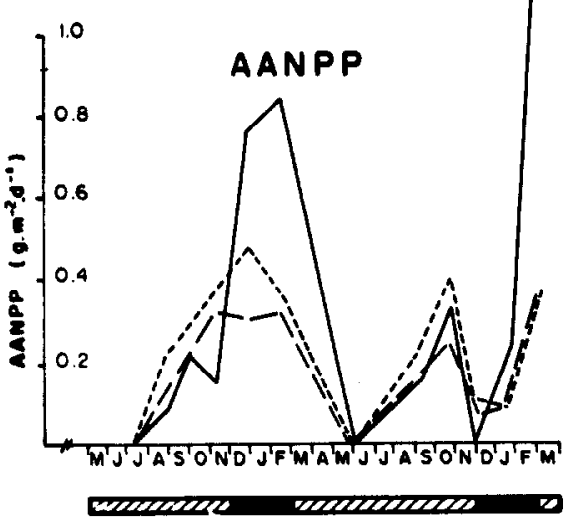

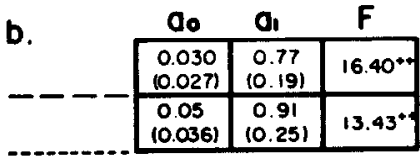

$d_{0}=0 \quad p<0.05$

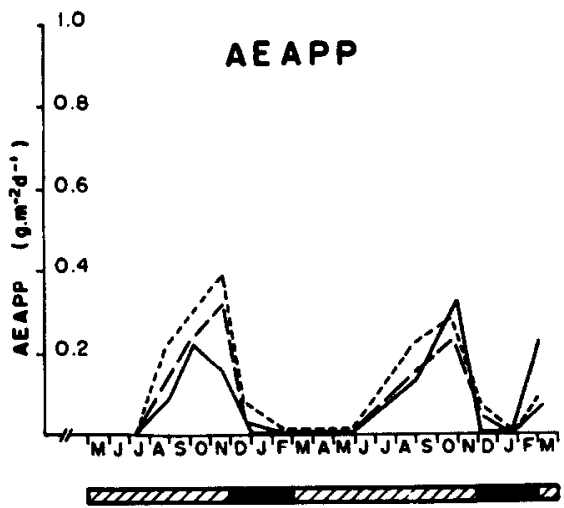

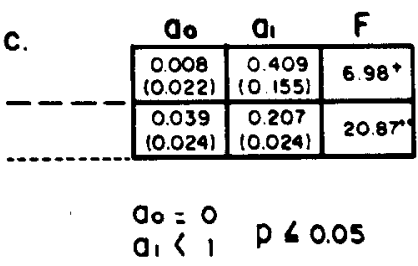

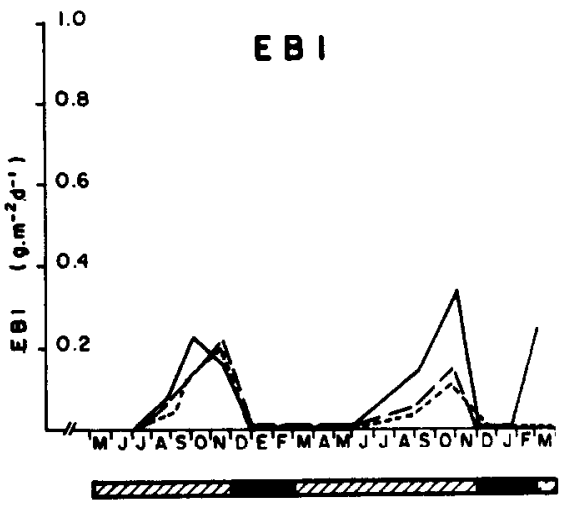

Fig. 3. Seasonal trends for (a) RANPP, (b) RAS, and (c) REAPP in ungrazed (solid line) and grazed (long dashed line: G=0.10, short dashed line: G=0.16 $\left.\mathrm{g} \bullet \mathrm{m}^{-2} \bullet \mathrm{d}^{-1}\right)$ treatments. Model coefficients and significance levels $\left(\mathrm{p}=0.05^{+}, \mathrm{p}=0.01^{++}\right)$contrasting grazed and ungrazed treatments are presented at top of figure. 
RANPP in the ungrazed area. Seasonal differences were significant as indicated by the equation parameters.

Relative aboveground senescence (RAS, Fig. 2b) was greater during the summer reproductive period (December to March). Rates were significantly less in the grazed than ungrazed treatment. Relative effective primary productivity (REAPP, Fig. 2c) peaked during August to November-December (end of the vegetative period-beginning of the reproductive period) in both treatments. Rates were significantly greater in the grazed than ungrazed treatment, as a consequence of greater RANPP during the vegetative phase and depressed RAS during the reproductive period.

Absolute aboveground net primary productivity (AANPP, Fig. 3 ) in the grazed treatment exceeded AANPP in the ungrazed treatment during the active growing season while the inverse was observed during the reproductive period. Absolute effective aboveground primary productivity (AEAPP, Fig. 3b), also differed significantly between treatments. Average AEAPP for the entire growing season was greater in the grazed than ungrazed treatment.

\section{Compensatory Response}

The effective biomass increase per unit of ground area (EBI, Fig. $3 c)$, in grazed plots $\left(G=0.10\right.$ and $\left.0.16 \mathrm{~g} \bullet \mathrm{m}^{-2} \bullet \mathrm{d}^{-1}\right)$ was less than in the ungrazed. The increased AEAPP did not compensate the losses of green tissues caused by grazing (G).

\section{Discussion}

Grazing increased both the relative and absolute aboveground net primary productivity (RANPP and AANPP) of coirón blanco during its vegetative period and depressed the same during the reproductive phenological stage. Increased RANPP and AANPP are in agreement with the increase of photosynthetic rates of grasses and graminoids after grazing reported by Caldwell et al. (1981) (Agropyron species), Parsons et al. (1983) (Lolium perenne), and Wallace et al. (1984)(Kyllinga nervosa, Themeda triandra and Hyparrhenia filipendula). Also Williamson et al. (1989) reported similar increases for Bouteloua gracilis at several levels of grazing intensity. The reduction of RANPP and AANPP caused by defoliation during the reproductive period is in accordance with the observations reported by Ruess et al. (1983) (Kyllinga nervosa) and Archer and Tieszen (1983) (Eriophorum vaginatum). As has been previously indicated by Scarnecchia and Kothmann (1986), results also emphasize the need to quantify senescence (RAS and AAS) when evaluating grazing effects, since differences in the aging occurred between ungrazed and grazed plants. When aboveground net primary productivity and senescence of coirón blanco were taken into consideration, grazing resulted in increased relative and absolute effective aboveground primary productivity (REAPP and AEAPP) during the entire growing season.

The results here shown validate some aspects of the grazing optimization hypothesis of McNaughton (1979) and Hilbert et al. (1981), which predicts increased aboveground net primary productivity at moderate grazing intensity. The terms over-, exact and undercompensation (Belsky 1986) have been conveniently suggested to clarify the various possible relations between the magnitude of the aboveground net primary productivity and that of the biomass removed by grazing. In the case of coiron blanco, the increases of REAPP and AEAPP were not of sufficient magnitude to compensate the losses of green tissues caused by grazing (G), thus resulting in undercompensatory growth in the sense of Belsky (1986). Considering the low rates of vegetation removal used in this experiment, it seems highly probably that overcompensation per unit of land area might not occur at any rate of herbage removal under continuous grazing of coirón blanco. This has practical consequences for the rational management of these rangelands. If a arget stocking rate is defined as that compatible with compensatory primary productivity on a land unit basis, then a reduction in stocking rates seems necessary to increase the aboveground primary productivity. This increase would compensate forage losses by grazing, thus preventing the deterioration of the resource. A regular program of biomass monitoring and model computation of the type here presented can help in finding adequate stocking rate levels for coirón blanco.

\section{Literature Cited}

Archer, S., and L.L. Tieszen. 1983. Effects of simulated grazing on foliage and root production and biomass allocation in an artic tundra sedge (Eriophorum vaginatum). Oecologia 58:92-102.

Ares, J.L. 1978. Un modelo de la dinámica de la biomasa aérea de tres especies dominantes de un pastizal patagónico. Deserta 5:45-56.

Ares, J.O., A.M. Beeskow, M.B. Bertiller, C.M. Rostagno, M.P. Irisarri, J. Anchorena, G.E. Defossé, and C.A. Meroni. Structural and dynamic characteristics of overgrazed grasslands of northern Patagonia, Argentina. In: A. Breymeyer (ed), Managed grasslands: Regional Studies. Elsevier, Amsterdam, (In press).

Beeskow, A.M., H.F. del Valle, and C.M. Rostagno. 1987. Los sistemas fisiográficos de la región árida y semiárida de la Provincia del Chubut. Secretaria de Ciencia y Técnica, Delegación Regional Patagonia. Bariloche, Argentina.

Bertiller, M.B. 1984. Specific primary productivity dynamics in arid ocosystems: a case of study in Patagonia, Argentina. Acta Oecologica/ Oecologia generalis 5:365-381.

Belsky, A.J. 1986. Does herbivory benefit plants? A review of the evidence. Amer. Natur. 127:365-381.

Boelcke, 0. 1957. Comunidades herbáceas del norte de la Patagonia y su relación con la ganaderia. Revista de Investigaciones Agricolas 11:5-98.

Caldwell, M.M., J.H. Richards, D.A. Johnson, R.S. Nowak, and R.S. Dzurec. 1981. Coping with herbivory: Photosynthetic capacity and resource allocation in two semiarid Agropyron bunchgrasses. Oecologia 50:14-24.

Hilbert, D.W., D.M. Swift, J.K. Detling, and M.I. Dyer. 1981. Relative growth rates and the grazing optimization hypothesis. Oecologia 51:14-18.

Kowal, N.E. 1971. A rationale for modeling dynamic ecological systems, p. 123-192. In: B.C. Patten (ed), Systems analysis and simulation in ecology. Academic Press, New York.

MeNaughton, S.J. 1979. Grazing as an optimization process: Grassungulate relationships in the Serengeti. Amer. Natur. 113:691-703.

Milthorpe, F.L., and J. Moorby. 1979. An introduction to crop physiology. Cambridge University Press, Cambridge.

Nemchenko, 0. 1987. A compartment model of metabolite utilization for plant growth. Ecol. Modell. 39:17-32.

Parsons, A.J., E.L. Leafe, B. Collett, and W. Stiles. 1983. The physiology of grass production under grazing. I. Characteristics of leaf and canopy photosynthesis of continuously-grazed swards. J. Appl. Ecol. 20:117-126.

Ruess, R.W., S.J. MeNaughton, and M.B. Coughenour. 1983. The effects of clipping, nitrogen source and nitrogen concentration on the growth responses and nitrogen uptake of an east African sedge. Oecologia 59:253-261.

Scarnecchia, D.L., and M.M. Kothmann. 1986. Observations on herbage growth, disappearance, and accumulation under livestock grazing. J. Range Manage. 39:86-87.

Scott, E.G. 1982. The sheepman's production handbook. Sheep Industry Development Program, Inc. Abegg Printing Co., Denver, Colo.

Soriano, A. 1956. Los distritos floristicos de la provincia patagónica. Revista de Investigaciones Agricolas 10:323-348.

Soriano, A. 1983. Deserts and semideserts of Patagonia, p. 424-460. In: N.E. West (ed), Temperate deserts and semideserts. Elsevier, Amsterdam.

Wallace, L.L., S.J. McNaughton, and M.B. Coughenour. 1984. Compensatory photosynthetic responses of three African graminoids to different fertilization, watering, and clipping regimes. Bot. Gaz. 145-151-156.

Williamson, S.C., J.K. Detling, J.L. Dood, and M.I. Dyer. 1989. Experimental evaluation of the grazing optimization hypothesis. J. Range Manage. 42:149-152. 